\title{
Race and Place: Introduction
}

\section{Abstract}

Purpose

The purpose of this paper is to introduce the special issue on Race and Place.

Design/methodology/approach

The approach used by the authors is to combine an overview of sociological debates on place within a framework that makes the case for a relational approach to race, space and place.

\section{Findings}

The overview provides an account of place in sociology, of the relationality of race and place, and the making of race and place in sociological work.

Originality/value

The Introduction sets the papers in context, providing a short account of each of them; it also aims to present an argument for attention to race and place in sociology in a setting characterised by racism and reaction.

Keywords

Racism, Space, Relational, Post-racial, Racialization 
[Place] is the vast complexity of the interlocking and articulating nets of social relations... [it is] always formed by particular sets of social relations and by the effects that juxtaposing those interrelations produce. Massey, 1994, p.168

Place is one of those strong representational coordinates of cultural identity. It [...] is grounded by distinctive ways of life, and as a kind of symbolic guarantee of stable, continuous, cultural patterns consistently reproduced through traditions that mirror the stability of kinship and blood ties among a settled, gathered, and interrelated population. Hall, 2017 [1994], p. 106

\section{Placing Sociology}

Two children are playing on a bright pink seesaw. The seesaw cuts across a vertical fissure in a dark brown wall, one of the many territorial divisions mushrooming across the world, in this case between the USA and Mexico. The contrast between the brightness of the seesaw and the darkness of the wall emphasizes the "tremulousness, vulnerability, dubiousness, or instability at the core of what [borders] aim to express" (Brown 2010: 24).

A sense of political sacrilege was one of the main effects of the project, which took place in July 2019, designed by Professors Ronald Rael and Virginia San Fratello. The entire action, which involved three seesaws installed across the border, neatly illustrates the key theme of this Introduction and this special issue - the quintessential relationality of place- 
making Two anonymous and marginal spaces became one single place, where "children and adults were connected in meaningful ways on both sides with the recognition that the actions that take place on one side have a direct consequence on the other side". "Recognition" stands out as a critical dimension, especially if viewed against the history of the "open wound", as Anzaldua (1987) memorably described the US-Mexico border: "una herida abierta, where the Third World grates against the first world and bleeds. And before a scab forms it haemorrhages again, the lifeblood of two worlds merging to form a third country -- a border culture" (1987: 3). There are so many ways in which spaces become places and vice versa (Massey 2005: 130-142). These permutations happen via social processes of distinction, domination, dis/possession and solidarity, governed by racial logics which deserve both close-up scrutiny and sociological theorization, especially in times of massive global displacement and dispossession (UNHCR 2016).

The relationship between space, place and race, and sociology's contribution to that, is the theme of this special issue. When Urry argued that "place (and space) should be central to sociology' (Urry 2004: 30) he was clearly signalling that was not the case; his essay examines some of the reasons why that is so, especially sociology's uneven engagement with them. While space was largely under-explored in classical sociology, Urry shows that space and place made a comeback in the 1970s and 1980s, through the works of Castells, Massey and Harvey. Significantly two of these three are primarily known as geographers rather than sociologists and this reflects the ways in which sociology has ceded space and place to geography in its exploration of dichotomises between urban and rural ways of life and forms of community life. Hence it appears that sociologists 'have given the appearance of not being interested in place-perhaps preferring to leave the matter to geographers.' (Gieryn, 2000: 464). Drawing on Massey's progressive sense of place in particular Urry goes on to 
make a case for a sense of place that is dynamic and mobile, not static; as spaces characterised and made up flows and networks, rather than any neatly bounded notion; and as spaces where difference, particularly gender and ethnicity are central. To an extent, the latter, especially through the interest in diaspora communities and multiple meanings of home, fuses all of Urry's elements of place as made up of flows of people and things across borders that also reflects his critique of the 'container' model of society (Urry 2000, 2001).

To develop this further we turn to another case or proposition for sociology of place, Gieryn (2000) also argues for a place sensitive sociology. Like others writing around this time (cf De Blij, 2009) his plea for attention to place is made in opposition to discussions of the time of globalisation as leading to the flattening out of place, even of 'placeleness' under conditions of increasing cultural and economic homogenisation (Hall 2017 also took aim at the same claim in his 1994 Harvard lectures). In opposition the authors here argue that place matters and requires more attention from sociology. What though, for Gieryn, is place? He identifies three core features: 'A place is a unique spot in the universe' (2000: 464), that is it has a distinct geographical location. Place has physical or material form and 'social processes (difference, power, inequality collective action) happen through the material forms that we design, build, use...” (2000: 465). And thirdly, place is something invested with meaning and value - it is, 'interpreted, narrated, perceived, felt, understood and imagined (Soja 1996)' (2000: 465). In turn, Gieryn emphasises what place is not - it is not 'just a setting, backdrop, stage or context for something else.... nor is it a proxy for demographic, structural, economic or behavior variables' (2000: 466). Moreover place is not space - which is a more abstract idea; place is space that is 'filled up by people, practices, objects, and representations' (2000: 465). This is a well-established contrast but regarded by others as somewhat dismissive of space. Logan (2012) calls for more spatial thinking of the relation between places while 
Shields (2013) regards place 'as a portion of space' (p.187). Shields adds the term 'place image' for a specific representation of place, and 'place myth' for a collection of representations of a place (Shields 2013).

If geography lays claim to be the science of place (De Blj 2009) is there a distinctive role for sociology? In this issue, we make the case that such a role for sociology can be founded on a distinctive empirical and theoretical orientation to investigations of the relations between place and race. Sociology's contribution to these discussions in terms of theorising and exploring the complexity of place and its varying relations to race, as part of the social relations that Massey (1994) points to, and Hall (2017) located in the context of cultural identity in the quotations at the start of this Introduction. With these considerations in mind, we organized in 2018 linked sessions on Post-racial Urbanities: A Global Cartography at the ISA Forum in Toronto, and Racial and Post-racial Senses of Place at the ASA annual meeting in Philadelphia. Six of the seven articles included in this special issue were presented at these sessions, which followed on a 2016 ISA Forum session that we organised and produced as a special issue on Racial Urbanities: A Global Cartography (Picker et al 2019). In that special issue, we called for new conversations about the racial and the urban conjointly, from global yet non-totalizing perspectives, against the background of rarely intersecting global scholarships on race on one hand and cities on the other.

Race and Place, this special issue, is precisely meant as one of those new conversations. In it, including this Introduction, our aim is to offer insights into that as well as a range of global scholarship that explores place and race conjointly, using ideas and methods that include reference to sociological thinking. Race and Place interrogates the ways in which race, space and place co-constitute the net of social relations in which certain human 
vulnerabilities are erased while others affirmed, and in so doing, both race and place participate in the perpetuation of asymmetries and injustice. While these questions often relate to or are framed in the context of the urban, which is why both our conference sessions and a number of articles in this collection deal with cities, here we aim to broaden the canvas and focus on a range of contexts across the national to the urban and specific borders and institutions. This widening aims to keep the contextual variety of space-place-race configurations in sight. For instance, the case of the seesaw project that we opened with expands the urban focus that the bulk of work of race and place may suggest; "migrant camps", another example we will briefly address in this introduction, is another case in point. Before that, we would like to review some of the conversations on these issues, and outline possible avenues for sociologically looking at place, space and race conjointly.

\section{Relational race-and-place making}

Drawing on the critical contributions of Massey (1994, 2005) and Hall (2017), especially the latter's point that place is 'a strong representational coordinate of cultural identity' (Hall 2017[1994]: 106), anchored in imaginary geographies and invented traditions of time and place. the central argument we make is that race and place are made in relation to one another. This is a stronger claim than merely noting that race and place are connected, or that place representations and national discourse are sometimes inflected with ethnic and racial overtones and discourses. Thus it is not that race is absent from some of the sources we have cited so far, but it is rarely central. To take a few examples: Urry (2001) looks more to ethnicity - rather than race - as important for the ways in which diasporas connect spaces and places across boundaries that call into question those very boundaries; while in Gieryn (2000) place is certainly important in showing and reinforcing social hierarchies and where ethnic enclaves have limited people's life chances. Other authors (De Blij 2009, Cresswell 
2015) link race to spatial segregation such as under Apartheid, or to exclusionary nationalist narratives but these tend to make racism exceptional rather than routine. Other work on race and place connects them in relation to health inequalities (Gasking et al 2014) or ecologies of urban policing and crime control (Hipp 2007) run into Gieryn's counter that place is not just a context for structural or behavioural variables. A closer look at sociological and geographical contributions to understanding relational race-place making shows the close connections between the two disciplines but also sociology's distinctive role.

The racialization of space and the spatialization of race relate to various dynamics involved in the (making sense of a) portion of a certain space that is inhabited, trespassed, dwelled, viewed and imagined (Lipsitz 2011; 2007; Neely and Samura 2009; Linke 2014; Kipfer 2007; Keith 2005). In doing so, a certain space acquires a certain degree of specificity and is, as such, recognizable, identifiable and provider of sources of identification, more or less ephemeral, that may appeal to certain individuals and collectives. In their important collection Place and the Politics of Identity, Keith and Pile (1993) expose the simultaneously contingent and autonomous power of place in providing platforms for various kinds of relational identifications, from the most protectionist and exclusionary to various forms of liminality, hybridity and togetherness. Place is continuously, relationally in the making.

These considerations foreground the production of space and its pivotal ability of rendering real what was only assumed as real - the solidifying function of space that is experienced and enacted through representations (Lefebvre and Nicholson-Smith 2009). Building on Lefebvre, Shields (2013) says that a geography of difference is needed to properly understand a sense of place through which each place is part of a relational spatial and temporal network 'distinguished not only by its proper place-myth but by its 
distinctiveness and contrasts with other sites.' (Shields 2013: 31). Among the most explicit examples are perhaps Massey's $(1984 ; 1988 ; 1993)$ works on the urban division of labour and how the crystallization of political economic projects onto the built environment acts as constitutive dimensions of value-making and various forms of exploitation. In this way, the spatial leaves the floor to its specific, place, which is not a passive but an active producer of boundaries, identifications, structural limitations and ultimately sociality in more or less hierarchical forms and meanings. Symbolic and material hierarchies are central to Bourdieu's (2009(1992)) sociological view on both physical and social space, shows how the two are mutually related via symbolic venues, which act in ways that end up being more powerful than typically perceived. And the anthropologist de Certeau (1984) focused on everyday places to capture the making of individual experiences of urban transit and dwelling, with their located tactics and strategies that contribute to design the anthropological worlds which urbanites inhabit.

It is at these variously configured intersections of the material(ist) and the symbolic that "senses of place" may be disassembled and rearranged by way of racial ascriptions, calculations or dispositions; philosophers of race are well placed for clarifying these operations. As "a way of being and being in the world", as a "political theology" (Goldberg 2009), race at times reinscribes the social and the spatial as co-constitutive modes of institutional and mundane positionings, of cunning planning and community attachments, of smart calculations and improvised resistances. Racial practices and conceptions are relational, as Goldberg (2015a) maintains, where local expressions are always tied to wider expressions and meanings. Goldberg's relational account entails what he calls two interactive claims. One, racial ideas, meanings and exclusionary practices in one place are influenced, shaped by and fuel those elsewhere'; and second, 'racist arrangements anywhere 
- in any place - depend...on racist practice almost everywhere else' (Goldberg 2015a: 2545).

Various spatial processes and their mutual interactions are always (re)made according to historical and dialectical dispositions to a certain degree shaped by the making of racial ascriptions, rules and grounds (Simone 2010). These rules and grounds play out at different scales and within multiple dimensions, with varying effects and mutations of reality.

Global policing stands out as illustrative case. Preventing policing reiterates an urban logic of border defence that is typical of warfare (Byfield 2018), thus linking the making of global, national and urban partitionings, which are being increasingly maintained and patrolled within the discursive framework of security as spectacle (Fassin 2013, Mireanu 2013; Mezzadra and Nielson 2013). This hierarchical bordering of spaces and places, by extension, becomes also a bordering of humanity that reiterates centuries of global domination in which whiteness became supremacist, as a source both actively enacted and unproblematically enjoyed. The solidification of whiteness, contained into proliferating super-security apparatuses of urban living (Benjamin 2009; Seamster 2015), gated sites of upper-class fragility, illustrates Hall's (1995: 54, quoted in Alexander 2009: 469) point that " 'I have never worked on race and ethnicity as a kind of subcategory. I have always studied the social formation which is racialised". No need to look for non-racial(ised) place.

Relatedly, while humanity as a construct, borne out of colonial conceptions (Barnett 2013; Fassin 2012), operates at the global scale of imaginaries in constituting and maintaining various forms of borders hierarchically, the centrality of human bodies in the making of senses of place draws attention to the proximate, the local and the immediately material (McKittrick 2019; Weheliye 2014). Considering both scales at once - the global and the local - allows attending to how spatial and temporal proximity becomes a condition for 
rising fears and desires in varying forms and intensities, coded and decoded through racial and sexual ways of inhabiting, knowing, desiring and structuring the world (Ahmed 2015(2004); McKittrick 2006). Human bodies and cities - the body and the city - have been the paired focus of important reflections (e.g. Sennett 1996; Thrift 2008), to which a raceconscious optic opens key and perceptive venues of critical interventions (Brown 2017; Brahinsky et al. 2014; Linke 1999).

One of the most comprehensive and insightful of these interventions comes from black geographies (Woods and McKrittick 2007; Allen et al. 2018; Hawthorne 2019) that, in merging the material and the symbolic, extensively discuss how "a black sense of place, $[\ldots]$ produced by and through processes of racialization" (McKrittick 2006: 27) is key to critically questioning and (re)shaping not only geography and views on spatial relations but also dominant sociological theories, in which typically "the black subject emerges as an external and spatial entity, a product of global relations that was brought into consideration as an effect of universal reason" (Simone 2010; see also Niaah 2006: 209).

Critically considering the colonial origins of social and geographical sciences, as well as the colonial genesis of dominant spatial logics such as segregation, gentrification and surveillance, black geographies seem to systematize and actualize in a space-conscious manner what Mills in The Racial Contract (1999) calls "political knowing". By that, Mills intends a disposition of "see[ing] differently, ridding ourselves of class and gender bias, coming to recognize as political what we had previously thought of as apolitical or personal, doing conceptual innovation, reconceiving the familiar, looking with new eyes at the old world around us" (1999: 123). Adding up the category and dimension of space to Mills' "biases", black geographies bring attention to what could be called the spatio-racial contract -- a tacit agreement that keeps racial hierarchies safely untouched, until the injustice of their racial logics and implications is unveiled, examined and opposed. 
From this angle, black geographies' provide a telling addition to Massey's (1991: 24)

call for a "progressive sense of place [...] beyond ethnocentricity", referring to urban residents' sense of rebellion vis-à-vis fast changes relating to the arrival of foreign workers and families in "their" neighbourhood. Indeed, adopting a "beyond ethnocentricity" approach would suggest a "non-political knowing" kind of perspective, rather than a race-conscious and politically situated one. This does not mean reducing analytical and action-oriented options to the sometimes misunderstood dimension of "identity politics". Anti-racist movements have always been aware (as dialectic proceeds by constant re-adjustments of partial syntheses) of both potentials and limits of identity politics, including in the US, where the notion has received and keeps receiving a substantial dose of scepticism. For instance, following Simone (2016: 193), "the commonality that Black Power worked during its heyday was less that of a shared racial identity than it was the making of common concert among disparate situations. It was a way of tying together the various strands of black life and empowering those strands by articulating them in new ways $[\ldots] "$.

Alongside black geographies we can also highlight some studies that locate apparent racial absences within white spaces in their imagined and relational forms. For example Back (1994) points to the complex interactions of race, class and gender hierarchies that are entangled in a specific setting, South London. The iconic notion of the English countryside and its coded whiteness and racial exclusions are brought to the fore in Neal and Ageyman (2006). In the in-between space of the English seaside town that is neither urban nor rural, Burdsey (2016) shows how the whiteness of the seaside both contains and expresses notions of racialized belonging and exclusion where racialized bodies are treated as 'out of place'. In drawing on intersections of race, class, gender and locating place in national and local histories such studies underscore sociological approaches to race and place. 


\section{Sociological Race-Place Making}

While acknowledging the growing and fruitful interdisciplinarity of this scholarship, we would like to propose some further aspects that appear to us typical of a sociological sensitivity. We will then locate the seven articles of this special issue within this sociological framing. As we already indicated, Hall's contributions over several decades appear as essential. In his analysis of Policing the Crisis (Hall et al 1978), Keith (2009) underlines the importance of maintaining the complexity of sociology of race in its historically informed imagination, when approaching spatial phenomena, especially those relating to the city:

crime, race and the ghetto could be conflated as social problems after incidents such as the clashes with police in Brockwell Park because they 'located and situated black crime, geographically and ethnically, as peculiar to black youth in the inner city ghettos' (Hall et al. 1978, p 329). For Hall the racialized iconography of place fuses together ethnicity, location and the spatial imaginaries of danger. These metropolitan spaces of anxiety have a history in the ways we have thought about and written about the city in the past. The rhetorical structure of urbanism's academic prose always deploys vocabulary that draws meaning from the ways in which terms such as the street, the square, the barricades, the agora have always performed the dual tasks of invoking (metonymically) a sense of city living at the same time as they attempt to describe (metaphorically) a particular social reality.(Keith 2009: 541).

Keith's insightful reading of Policing the Crisis reveals a seemingly typical sociological disposition toward race-place relationality, one that foregrounds institutions 
such as the state and the market rather than the generative role of space, as geography, instead, tends to do. A brief review of the Sociological Abstracts database shows that articles in Sociology journals that feature both "race" and "place" in the title usually foreground the role of institutions, especially the state in its articulations such as the police and social welfare, as indeed Hall et al (1978) did. The first of these articles appeared in the early 1990s, and from the 1990s to the 2000s their number stunningly increased by almost three times, from 49 to 142 , slightly decreasing to 106 in the 2010 s. While in the 1990s, race-class formations in urban settings were a prevailing topic, in the 2000s this topic remained but the structural role of institutions, especially the police, emerged as pivotal, and remained throughout the 2010s. In the UK, this was to a certain extent induced by the Macpherson report in the aftermath of Stephen Lawrence's murder in 1993 (Murji 2017: 65; 81). In the US, post-9/11 criminalization and increasing mass incarceration were indeed crucial social phenomena that attracted sociological attention.

More generally, when sociologists approach the relations between race and place, issues of class, gender and racial justice seem to often intersect institutional power. This is reflected in the papers in this special issue. An explicit instance of the centrality of state power in race-place relationality is Bonar Buffam's analysis in this special issue of the Vaisakhi celebrations in 21st-century Vancouver. Buffam (2019) meticulously reviews various actions and discourses of politicians, law enforcement and military personnel in extending their racial authority over Sikh urban places. Through "postracial" modes of dissimulating their power through discourses of diversity and accessibility, these various state agents strictly regulate and discipline Sikh places of sociality and politics. Not far from Vancouver, in Toronto, Shana Almeida's contribution sharply shows the pitfalls of the (discourse) of minority inclusion in 
decision making processes. By critically examining policy documents from 1975 to 2017 concerning various initiatives of collegial deliberations involving "racial Others", the author discloses "the violence of diversity discourse" that objectify groups and their place in the city. Almeida (2019) concludes by suggesting a reflexive scepticism vis-àvis the often celebrated involvement of racial others as per se a solution to the problem of racism.

Brazil provides an even more explicit illustration of the role of the state in solidifying racist conceptions of place attachment and relationality. In his comprehensive intervention in the established literature on segregation in the country, Ricardo Rotondano (2019) unearths black experiences in the city of Salvador that constitute a structural politics of apartheid. The author argues that such state politics is historically rooted in the making of Brazil as a racial democracy, as well as in land valorization and urban modernization policies that have continuously disenfranchised black folks.

Strictly related, Seegio Rocha Franco's (2019) comparative analysis of Brazilian's racial democracy and South Africa's rainbow nation is centred on a multi-focal ethnography in Rio's favelas and Johannesburg's townships. Yet in linking the urban and the national the author highlights the gaps between residents' racialized sense of place and experiences of everyday life and a national rhetoric which emphasizes efforts toward equal citizenship rights in both countries. This rhetoric and efforts end up masking racial oppression, thus siding with familiar postraciality, which Rocha Franco identifies as the true obstacle in the way of making visible and opposing racism.

City spaces and urban splittings are central to Nicole Trujillo-Pagan's (2019) article too. Taking a Latina/o/x neighbourhood of Detroit as location and the production of graffiti as a case study, the author originally bridges the creative cities and the urban 
marginality literatures. By illustrating the various interests and relations at stake in the creative field of graffiti, the study concludes that creative economies and a public rhetoric of creative urban development contribute to reproduce social inequalities.

Spatiality as a quintessentially racialized dimension emerges in David Embrick et al's (2019) ethnographic study of the Art Institute of Chicago. The authors discuss both various dynamics happening inside the museum and the contents of the exhibitions, arguing that white spaces such as contemporary art museums reproduce the racial order making white people feel proud of their accomplishment. The intersection of both phenomenological observations and more general considerations around curatorial politics allow the authors to expose and critique "post-racialism" in some of the most banal and considered "innocent" locations such as museums.

The issue of space, place and race does not only play out in physical formations. Gavan Titley's (2019) article on racialized spatial imaginary in Sweden's mediascape both resonates with and expands from the other authors' points. By taking one of President Trump's many anti-immigration discourses, the author analyses the construction of Sweden as a racialized space that is built to contain racial fears and terror within the emotional politics of racism shared among growing fractions of farright and conservative politicians.

Contemporary manifestations of hyper-restrictive migration policies may take the form of postracial state violence, articulated with (and bound to) place. These attempts to impose some kind of "postracial sense of place" appear alongside a more general and better-known self-obfuscating contradiction and the very displacement of race it amplifies. One illustrative case of this form of violence can be found close the US-Mexico border, where we began our discussion, and concerns the USA law enforcement's management of camps for individuals and families who crossed the US- 
Mexico border from Central America, animated by various projects and longings. A US government report, dated July 2nd, 2019, shows the highly overcrowded conditions of detainees, and a more recent government visit has documented the separation of children from their families, with children detained in the "Ursula" Centralized Processing Center in McAllen, Texas.

This system of encampment that, as many others across the world, renders camp facilities inhabitable both materially and existentially (Picker and Pasquetti 2015), reminds the "slow violence" that Nixon (2013: 2) describes as "a violence occur[ing] gradually and out of sight, a violence of delayed destruction ... dispersed across time and space, an attritional violence that is typically not viewed as violence at all". The racial constitution of the history and politics of US-Mexican relations, exacerbated by President Trump's connotation of Mexicans as "animals", "drug dealers, criminals and rapists",iii reinforces the racial connotation of camps" "slow violence". As such, not being “viewed as violence", "slow violence" not only dissimulates its racial connotation, but also normalizes the camps and the inhuman conditions of the detainees. This gives those "places" a (apparent) "sense" of postracial (violent) normality, that confirms Goldberg's (2015b: 76; 82) points: "Postraciality [...] renders opaque and invisible the terms by which the charge of racism against its historical agents or their inheritors is realizeable. [...] It effectively erases any record of raciality".

While mentioning camps, violence and postraciality may seem like one and or an extreme case, we are pointing to those as part of a continuum as well as posting their centrality in contemporary political discourse, as a technology of government and in global necropolitics. This indicates the ways and the extent to which a concern with race and place is or should be a key issue for the social sciences. We hope this special issue makes a useful 
contribution to understanding their interrelation and to a developing sociologically grounded research agenda.

\section{Notes}

\footnotetext{
${ }^{\text {i }}$ Professor Ronald Rael Instagram post, 30 July 2019 https://www.instagram.com/p/B0fY2R6hfKr/?hl=en. ${ }^{\mathrm{ii}} \mathrm{https}$ //lasentinel.net/trump-calls-mexicans-animals-again-and-white-house-advisorsattempt-to-justify-it.html

iii https://www.theatlantic.com/magazine/archive/2019/06/trump-racism-comments/588067/
}

\section{Acknowledgment}

We thank the reviewers - who we cannot name - of the papers in this issue for their thoughtful and helpful comments. We also thank Nicole Trulljo-Pagan for reading a draft of this Introduction.

\section{References}

Ahmed, S. (2015). The cultural politics of emotions. New York: Routledge.

Alexander, C. (2009). Stuart Hall and 'Race', Cultural Studies, 23:4, 457-482,

Allen, D., Lawhon, M. and Pierce, J. (2018). Placing race: On the resonance of place with black geographies. Progress in Human Geography, 43(6), pp.1001-1019.

Almeida, S. (2019), "Mythical encounters: challenging racism in the diverse city", International Journal of Sociology and Social Policy, https://doi.org/10.1108/IJSSP-112018-0198

Back, L., 1994. The 'White Negro'revisited. In Andrea Cornwall and Nancy Lindisfarne (eds) Dislocating Masculinity: comparative ethnographies, London: Routledge

Barnett, M.N. (2013). Empire of humanity : a history of humanitarianism. Ithaca, Ny: Cornell University Press.

Benjamin, R. (2009). Whitopia : an improbable journey to the heart of white America. New York: Hyperion. 
Bourdieu, P. (2009). The weight of the world: social suffering in contemporary society. Cambridge Polity Press.

Brahinsky, R., Sasser, J. and Minkoff-Zern, L.-A. (2014). Race, Space, and Nature: An Introduction and Critique. Antipode, 46(5), pp.1135-1152.

Buffam, B (2019) Political appearances: Race and the Places of State Authority in Metro Vancouver's Vaisakhi Celebrations, International Journal of Sociology and Social Policy,

Burdsey, D. (2016). Race, place and the seaside: Postcards from the edge. London: Palgrave

Byfield, N.P. (2018). Race science and surveillance: police as the new race scientists. Social Identities, 25(1), pp.91-106.

De Blij, H. (2009). The power of place: Geography, destiny, and globalization's rough landscape. Oxford University Press

De Certeau, M. (1984). The practice of everyday life. Berkeley: University Of California Press.

Embrick, D., Weffer, S. and Dómínguez, S. (2019), "White sanctuaries: race and place in art museums", International Journal of Sociology and Social Policy, https://doi.org/10.1108/IJSSP-11-2018-0186

Fassin, D. (2012). Humanitarian reason: a moral history of the present times. Berkeley: University Of California Press.

Fassin, D. (2013). Enforcing order: An ethnography of urban policing. Cambridge: Polity.

Gaskin, D.J., Thorpe Jr, R.J., McGinty, E.E., Bower, K., Rohde, C., Young, J.H., LaVeist, T.A. and Dubay, L., 2014. Disparities in diabetes: the nexus of race, poverty, and place. American journal of public health, 104(11), pp.2147-2155.

Gieryn, T.F., 2000. A space for place in sociology. Annual review of sociology, 26(1), pp.463-496

Goldberg, D.T. (2009). The threat of race: reflections on racial neoliberalism. Malden, Ma: Wiley-Blackwell.

Goldberg, D.T. (2015a). Racial comparisons, relational racisms: Some thoughts on method, in Murji, K. and Solomos, J. eds., 2015. Theories of Race and Ethnicity. Cambridge: Cambridge University Press. Pp. 251-262

Goldberg, D.T. (2015)b. Are we all postracial yet? Cambridge: Polity.

Hall, S. (2017). Selected political writings: The great moving right show and other essays. Durham: Duke University Press. 
Hall, S. (ed.) (1978). Policing the crisis. Houndmills: Macmillan Education.

Hawthorne, C. (2019). Black matters are spatial matters: Black geographies for the twentyfirst century. Geography Compass. Online First, DOI: 10.1111/gec3.12468.

Hipp, J.R., 2007. Income inequality, race, and place: Does the distribution of race and class within neighborhoods affect crime rates?. Criminology, 45(3), pp.665-697.

Keith, M. (2009). Urbanism and city spaces in the work of Stuart Hall. Cultural Studies, 23(4), pp.538-558.

Keith, M. (2005). After the cosmopolitan? : multicultural cities and the future of racism. London; New York: Routledge.

Keith, M. and Pile, S. eds., 1993. Place and the Politics of Identity. London: Routledge.

Kipfer, S. (2007). Fanon and Space: Colonization, Urbanization, and Liberation from the Colonial to the Global City. Environment and Planning D: Society and Space, 25(4), pp.701726.

Lefebvre, H. and Nicholson-Smith, D. (2009). The production of space. Malden, Ma; Oxford: Blackwell.

Linke, U. (2014). Racializing Cities, Naturalizing Space: The Seductive Appeal of Iconicities of Dispossession. Antipode, 46(5), pp.1222-1239.

Linke, U. (1999). German bodies : race and representation after Hitler. New York:

Routledge.

Logan, J.R., 2012. Making a place for space: Spatial thinking in social science. Annual review of sociology, 38, pp.507-524.

Massey, D. (2005). For space. London: Sage.

Massey, D. (1988). Global restructuring, local responses. Worcester, Mass.: Graduate School Of Geography, Clark University.

Massey, D., 1994 Space, place and gender. Cambridge: Polity

Massey, D. (1991). A Global Sense of Place. Marxism Today, (June), 24-29.

Massey, D. (1984). Spatial divisions of labour. London Macmillan.

McKittrick, K. (2019) “Rift”, in Keywords in Radical Geography: Antipode 50.

McKittrick, K. (2006). Demonic grounds: Black women and the cartographies of struggle. Minneapolis: Univ. of Minnesota Press. 
McKittrick, K. and Clyde Adrian Woods (2007). Black geographies and the politics of place. Cambridge, Mass.: South End Press.

Mezzadra, S. and Neilson, B. (2013). Border as method, or, the multiplication of labor. Durham: Duke University Press.

Mills, C.W. (1999). The racial contract. Ithaca ; London: Cornel University Press.

Mireanu, M. (2013). The Spectacle of Security in the Case of Hungarian Far-Right Paramilitary Groups. Fascism, pp.1-26.

Murji, K. (2017). Racism, policy and politics. Bristol: Policy Press.

Neal, S. and Agyeman, J. eds., 2006. The new countryside?: Ethnicity, nation and exclusion in contemporary rural Britain. Bristol: Policy Press.

Neely, B. and Samura, M. (2011). Social geographies of race: connecting race and space. Ethnic and Racial Studies, 34(11), pp.1933-1952.

Niaah, "Mapping Black Atlantic Performance Geographies: From Slave Ship to Ghetto,", in Mckittrick, K. and Clyde Adrian Woods (2007). Black geographies and the politics of place. Cambridge, Mass.: South End Press.

Nixon, R. (2013). Slow Violence And The Environmentalism Of The Poor. Cambridge, Massachusetts: Harvard University Press.

Picker, G. Murji, K. and Boatca, M. (2019). Racial urbanities: Towards a global cartography. Social Identities. 25(1): 1-10.

Picker, G. and Pasquetti, S. (2015). Durable Camps: The State, the Urban, the Everyday. CITY: Analysis of Urban Trends, Culture, Theory, Policy, Action, 19(5): 681-88.

Rocha Franco, S. (2019), "Favelas and townships: place making, everyday racialization, and the postracial", International Journal of Sociology and Social

Policy. https://doi.org/10.1108/IJSSP-04-2019-0087

Rotondano, R. (2019), "Brazilian apartheid: racism and segregation in Salvador, Brazil", International Journal of Sociology and Social Policy. https://doi.org/10.1108/IJSSP12-2018-0228

Seamster, L. (2015). The White City: Race and Urban Politics. Sociology Compass, 9(12), pp.1049-1065.

Sennett, R. (1996). Flesh and stone: the body and the city in Western civilization. London: Faber And Faber.

Shields, R., 2013. Spatial questions: Cultural topologies and social spatialisation. London: Sage. 
Simone, A. (2010). City life from Jakarta to Dakar: movements at the crossroads. New York: Routledge.

Simone, A. (2016). City of Potentialities: An Introduction. Theory, Culture \& Society, 33(78): 5-29.

Soja, E.W., 1996. Thirdspace: Expanding the geographical imagination. Oxford: Blackwell.

Thrift, N.J. (2008). Non-representational theory: space, politics, affect. London: Routledge.

Titley, G (2019) Taboo News about Sweden, International Journal of Sociology and Social Policy,

Trujllo-Pagan, N (2019) Marking Walls and Borders, International Journal of Sociology and Social Policy,

Urry, J., 2000. Sociology beyond societies: Mobilities for the twenty-first century. London: Routledge.

Urry, J (2001) 'The Sociology of Space and Place', in Blau, J.R. ed., The Blackwell companion to sociology. Oxford: Blackwell, pp.3-15

Weheliye, A.G. (2014). Habeas viscus: racializing assemblages, biopolitics, and black feminist theories of the human. Durham: Duke University Press.

References: 